\title{
Teachers' Protest Movements and Prospects for Teachers Improved Welfare in Uganda
}

\author{
Rose B. Namara ${ }^{1}$, Josephine Kasaija ${ }^{1}$ \\ ${ }^{1}$ Uganda Management Institute, Uganda \\ Correspondence: Rose B. Namara, Uganda Management Institute, Uganda
}

Received: March 18, 2015 Accepted: April 1, $2015 \quad$ Online Published: March 22, 2016

doi:10.11114/jets.v4i5.1482 URL: http://dx.doi.org/10.11114/jets.v4i5.1482

\begin{abstract}
Since the early 40s to today, teachers in Uganda organized themselves into unions and demanded for better conditions of service. Despite the long history of different forms of teachers' protests, the contribution of these protests towards influencing the teacher's welfare in the country is not sufficiently analyzed in the academic and policy circles. Up till now, it is not very clear what these protests have achieved. Written against the background of teachers' protests in Uganda, this paper examines the effects of collective action of teachers on their welfare. Interviews with Uganda National Teachers Union Staff, Primary School Teachers, and Ministry of Education and Sports officials indicate that, teachers protests movement have enabled to show the public that teachers are unfairly remunerated and have also contributed to some incremental changes in teachers' salaries and provision of some housing facilities by government. However, these protests have had minimal contribution to a policy and institutional framework that favour sustained improvement in teachers' welfare as these protests are recurrent. The findings suggest that prospects for teachers' protests to cause welfare changes in lives of teachers reside in proper mobilization of different categories of teachers as well as teachers' ability to broadly link their welfare to professionalism and attainment of the education outcomes.
\end{abstract}

Keywords: teachers protests, teachers welfare, teachers professionalism, Uganda

\section{Introduction}

This paper is about teachers' protests and the effects of these protests on teachers' welfare. Welfare is a big factor in employee motivation and productivity. Improving employee's welfare enhances loyalty and morale, industrial relations and industrial peace. Employee welfare also reduces labor turnover and absenteeism, thereby improving employee productivity. According to Jet HR, the welfare measures such as provision of allowances, housing, transportation, medical insurance and food are critical to employee health, happiness, and fortunes. Susanne Jacobs (2014) contends that employee welfare and work environment in general is affected by the reward and performance management processes, targets, resource allocation, and leadership style, each of which requires a clear structure and strategy. Similarly, it is further asserted that the factors that contribute to teachers' welfare include higher salaries, better staff relations, adequate facilities and equipment improved physical environment, lighter workload, and fair supervisors' treatment and continuity of contract (Goesalin, 1946 in Martha et al, 1949). In the same works of Martha et al., Gibbs (1947) note that teachers always seek for employment which offer professional inducements, where teachers are regarded as adult citizens, given fair salary schedules, given adequate retirement provisions, and provided with suitable living conditions.

In Uganda, welfare has been an issue for teachers as far back as 1944 when teachers under the Uganda African Teachers Association (UATA) presented 'their first memorandum on their- salaries and conditions of work, this issue has persisted to date. Continued teachers protests and strikes over the years is a clear indication of the unresolved issues surrounding teachers' welfare and government action on the contested issues. The teachers have continued to organize themselves into collective industrial action, and have also utilized advocacy to put pressure on government to yield to teachers' demands regarding their welfare. This paper seeks to examine the nature of teachers' protests in Uganda, how they have been organized and the overall effect of these protests on teachers' welfare. The first section of the paper links teachers protest movements to social movement and the whole theoretical framework of collective action. It presents the research problem as well as research methods. The second section provides findings from the historical 
analysis of teachers movements in Uganda, and gives the characteristics of teachers' collective action over time. The third section discusses how teachers unions have affected the teachers' welfare.

\subsection{Social Movements, Collective Action and Protest Movements}

Protest movements are functions of social movements. Social movements arises when oppressed people without political and economic leverage experience indignation over their conditions of life, and mobilize massively to promote or resist changes in the structure of society in order to gain or secure their rights. Thus, in times of threat and distress, people are more likely to consider themselves helpless and come to believe that they have the capacity to change their lives. For instance, in the nineteenth century, French Teachers' Movement who experienced church domination which had taken away their professional liberty, identified this issue as the single most important area of concern for collective concern. This eventually made their movement successful (Nicholas Toloudis 2008).

Literature suggests that there are two forms of social movements, the old and the new movements. The Old forms of social movements were characterized with principles and democratic form of collective will formation, claims for social justice, defense of social equality and rebellion with moral anger or protest of accepting suffering and oppressions. From the history of US, it is indicated that mass mobilization of black people forced the federal government to make concessions on a number of issues. Mobilization was done through segregated institutions i.e. church, and black colleges. In essence old forms of social movements were composed of defiant local mobilizers connected to other local organizations with similar aims through formal and informal networks.

Do these forms of organization characterize teachers' movements in Uganda?

The old forms of social movements are known for succeeding to mobilize marginalized sectors of society to challenge social injustices (Wolff, 2007). Social movements such as trade unions, have created space for the poor to change socio-economic and political systems e.g. the case of French Teachers movement (Toloudis, 2008), engage systems of governance and challenge unequal power relations, such as the women' movement. Similar movements in Uganda have manifested in form of protest movements of workers and farmers of the 50s and 60s against colonial powers that ultimately led to independence and creation of political parties to democratize the Country.

Literature on social movements suggests that movements are likely to benefit more from protests than organized structures because such structures can easily be influenced by government bureaucracies. According to Good fellow (2013) social movement can trigger and sustain growth of informal systems and create incentives for people to adhere to them thereby creating patterns of doing things. Several scholars (Goodfellow, 2013, Toloudis, 2008, Wolff, 2007) show a number of associated structural (formal and informal) and welfare changes related to social movements and also link these benefits to characteristics of movements which generally relate to organizational ability, resource mobilization, and collective action. Thus, investigating the institutional changes (formal/, informal) emerging from the teachers' protest movement will highlight the long term successes of their collective action.

The New Social Movements are linked to democratization processes, less emphasis on riots, and more emphasis on convenient collaborations for single issue social action. The new social movements are geared towards replacement of economic classes as centres of power with social movements. Social movements became a conglomeration of all groups/social classes that combine efforts to address an issue of common concern. The institutionalization of social movements' concerns manifests in inter-organization of social movements, new rise of interconnections between civil society and the state and the economy. The limitation with such perspective is that a multi-class grouping may not easily have shared interests, objectives or goals-making it difficult to organize for a common purpose. The new social movements demand intensive communication, mobilization and are likely to lead to increasing participation of various actors in the policy arena. This suggests the need to investigate whether and how teachers' movements have linked with other social networks and organization to pursue a common cause. What has been their mobilization strategy and how does this help in institutionalizing their common concern- welfare?

Irrespective of the new or old forms, social movements are characterized by a collective project that transcends the individual interests of those involved. Thus, depending on the issue of common concern, protests can be forged by teachers at different levels and /or all levels with different actors. This suggests that identification of issues of common concern and alliances that are forged along the way is important in understanding the effect of protest movements of teachers on their welfare. What is the issue of common concern around which teachers protest movement are organized in Uganda? And, who are the other actors that identify with the issue of common concern?

The survival of new social movements depends on their capacity to keep control of their stakes in public discourse, on successful communication of symbolic packages that resonates with their respective constituencies. Being part of public discourse, protest can be in form of strikes, use of mass media use of loudspeakers, and newspapers. While the use of voice is an option available to express dissatisfaction it is heavily dependent on the population's readiness to complain. 
Goodfellow (2013) shows that even when the population resorts to use of voice to express themselves, if this is done in a context where the state is unresponsive, the population's expressions degenerate to just 'noise'. Nevertheless, the main outcomes of new social movements are competitive occupation of the public space-placing the issue being contested in a policy domain, and, an emergence of different coalitions of collective actors.

While social movements (old and new) may seemingly have common characteristics Wolff (2007) comparative analysis of urban protest in Rwanda and Uganda show that they adopt different organizational strategies. Literature about teachers' movements shows that aspects of both the old and new social movements have manifested in their protests.

In the context of teachers' protest movements in Uganda, the questions of collective concern, strategies used as well as the effects being noted are a major area of interest in this paper

\subsection{The Problem}

The Ministry of public service in Uganda provides a clear description of teachers' welfare system which includes salaries, allowances and benefits. For instance, all permanent teachers, on the payroll, are entitled to retirement benefits; including a monthly pension commensurate with a teachers rank, salary and length of service, and a gratuity paid at the beginning of the retirement. Teachers working in "hard to reach" districts, defined as "hard to stay and hard to work in", and characterized by "remoteness, insecurity and poor infrastructure"; are entitled to a hardship allowance. However, teachers in Uganda have consistently been disgruntled by the low remunerations which according to them do not measure up to their welfare needs. They are increasingly de-motivated to the extent that $84 \%$ of teachers in active service are willing to leave the profession (Ministry consultative council meeting, October 2013, cited in UNATU, 2013). This limited motivation is further reflected in deteriorating teaching, performance and learning outcomes (UNATU, 2013). The low quality of education being provided has put teachers on spot light and disapproval by politicians, parents and communities. UNATU (2013) maintain that low pay, late pay, and no pay affect the morale of teachers and their image in society. This suggests that teachers' welfare in terms of monetary and non- monetary aspects needs to be improved. This has the core area of concern and the essence various teachers' protests and strikes in Uganda The contribution of these protests towards influencing the teacher's welfare system in the country is however not sufficiently analyzed in the academic and policy circles. The central question is; what have these protests achieved? This paper focuses on analyzing teacher's protests by Uganda National Teachers Union (UNATU) and its effects on teachers' welfare.

\subsection{Methodology}

To analyze the effects of teachers' protest movements on teacher welfare in Uganda, this study examined the teacher's issue of mutual concern, and, the different strategies utilized by their union towards teachers' welfare. The core questions asked are; what effect has the collective actions of teachers in form of protests had on teachers' welfare? What have been the forms of protests by teachers and what has been their main concern? In what ways has this concern been articulated? The conceptual framework below suggests that the Teachers' welfare in terms of salaries, housing, medical, is dependent on teachers' protest movements. The analysis assumes that an effective welfare system is dependent on teachers' ability to articulate their issue of collective concern, mobilize teachers, build alliances (supporters), and engage effective protest strategies

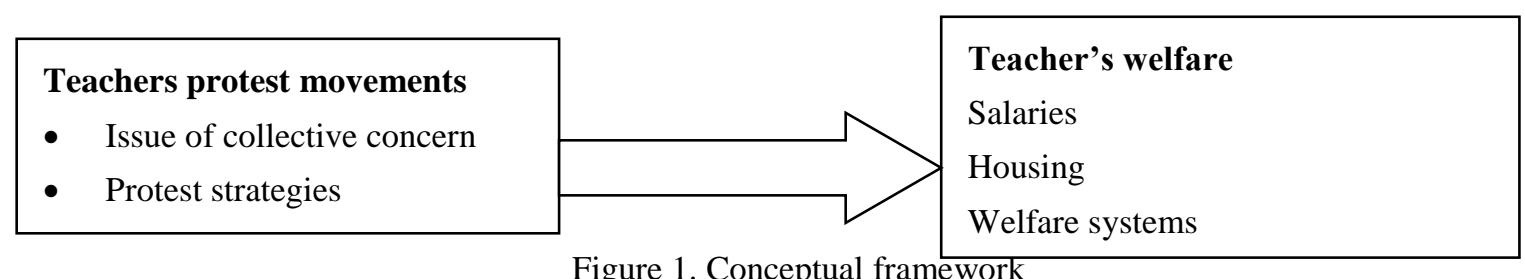

Figure 1. Conceptual framework

As indicated in figure 1, the author conceptualized Teachers' welfare as dependent on the issue of collective concern and the strategies utilized in protest movements. Thus, to examine the outcome of teachers protests (changes in welfare), this study examined the protest strategies used by teachers, and their articulation of the issue of collective concern. Actually, the core questions analyzed are;

- How have teachers organised themselves around the issue of collective concern?

- What strategies have they utilized to demand for improved welfare?

- What effect has the collective actions of teachers had on teachers' welfare?

- Are teachers' protests hurting or helping the teachers' welfare? 
- Under what circumstances would teachers protest movements lead to desired teachers welfare

In terms of data collection, this study adopted qualitative and historical analysis to explore the effect of collective actions of teachers on their welfare. The study utilized literature review, in-depth interviews, and focus group discussions as methods of data collection. The in-depth interviews were administered among UNATU officials, teachers from selected schools, and government officials. The focus group discussions were administered on students of public policy on governance studies at Uganda Management Institute who were undertaking a module on social policy analysis.

\section{Findings}

\subsection{The Issue of Collective Concern- a Historical Perspective}

Teachers' welfare has been an issue since 1940s due to very low wages that were paid by churches which were in charge of schools then. This period was characterized by silence protest since open protest would cause one to lose their jobs. However, despite the low salaries, teachers were comparatively better off than other workers and they enjoyed a good amount of respect in society.

The emergence of new better paid cadres such as cleaners, clerks, askaris, interpreters and general low grade workers in the offices of European administrators opened teachers 'eyes' to the fact that they were actually being underpaid. The less educated European administrator would be paid far better than teachers (Tiberondwa, undated). Despite this knowledge, the African teachers did not protest openly because of two reasons; a) every white person was seen as a ruler, symbolized power and questioning them was not popular; b) teachers feared losing their jobs on earth and their seats in heaven; they did not want to antagonize the employer- the European missionary. If at all one lost a job he/she stood little chances of regaining such employment in another missionary school- all schools were run by the European administrators. This patronizing relationship between the teaching professions and their employer appear to have laid a foundation for the determinants of a pay and motivation system.

\subsubsection{Early Attempts to Protest}

The certification of teachers, and the increasing numbers of qualified teachers in the 1940s gave teachers confidence to disagree with their employers. For example, in 1936, missionaries wanted to withhold salaries for teachers during holidays but certified teachers put up a spirited fight against it and they won. Despite the certification, teachers would not easily shift from a catholic to a protestant church based school. This angered some teachers, who felt their certificates did not grantee them much freedom. Some qualified teachers protested this unfair treatment by opening schools of their own. Private schools such as Aggrey Memorial School was opened by Dr. Ernest Kalibala. With this level of improved confidence, some teachers eventually convinced other teachers to join them to resist dictatorship and exploitation. It is acknowledged that Aggrey Memorial School became a centre of 'the nationalism and political activities which led to the formation of political parties in the nineteen-fifties'. These can be likened with the defiant mechanisms of old movement systems of mobilization as noted by Wolff, 2007 and Good fellow (2013) above.

From 1942, Uganda saw increased activity in form of teacher protests. A group of teachers reviewed their working environment, the treatment by missionaries, and found it to be inhuman. They protested through writing to the Director of Education seeking to explain their grievances. These included; limited consultations in decision making regarding their conditions of employment; lack of improved salaries for many years; and the dismissal or transfer of teacher who questioned the priest's decisions.

The Director delegated the issue to the Secretary of Education based in Mbale (a missionary) to handle the matter. This angered the teachers who organized fragmented collective efforts. For instance, The African School Teachers Association" (ASTA) formed in Mbale organized the first protest against poor salaries in 1942. In 1943/44 the Baganda teachers under the Uganda African Teachers Association (UATA) demanded improved teachers' salaries and conditions, the need to promote the status of teaching profession; effect high professional qualifications; and be allowed to be affiliated to national and international organizations. The demands yielded some salary increment of 10 per cent for the unmarried teachers and 15 per cent for teachers who were married and had more than one child.

Tiberondwa however notes that clearly the teachers' organizations (ASTA, and UATA) had a weakness of not involving other teachers like the Asians and other social groupings in the country. Thus, the genuine but fragmented efforts attracted counter organization such as "The Catholic Teachers' Guild" in Mbarara. These aimed at improving education controlled by the Catholic Church. Given the disjointed efforts, the teachers realized that they must pull their forces together in order to fight for their rights (Tiberondwa, undated). The two associations therefore were combined and the Teachers agreed to form an association of all teachers in Uganda. And in 1958, the name was changed to the Uganda Teachers Association (UTA) and their constitution was amended to allow non-African teachers to join. 
Despite the re-organization, the teachers continued to organize in a disjointed manner. For instance, secondary school teachers (members of UTA) were somehow comfortable- they received comparatively higher salaries, and had decent houses. On the other hand, the Primary and Junior secondary school teachers were less comfortable and they formed their own organization called -The Primary and Junior Secondary Teachers Union (UPJU). This organization came out clearly as a trade union than a professional body. Later on, UPJU changed its name of Uganda Teachers Union (UTU) to allow teachers of all categories to become members.

The UTU was very popular in the late 50s and early 1960's and it attacked UTA on the grounds that the latter was co-opted by Ministry of Education and could not truly serve the interest of the teachers. While UTA promoted the philosophy of professionalism, UTU maintained that teachers' conditions would not change if only they traded the professionalism ideology. UTA believed that professionalism is the first weapon to fight for better conditions of service and it was equally militant, although its code did not encourage militancy rather it advocated for good professional conduct.

UTA had by 1969 mobilized 12,000 members, established a headquarter building, represented teachers on most decision making bodies, arranged for teachers refresher courses and made sure that all teachers are employed by government. Often the Ministry of Education showed that it did not recognize the UTU and promoted the UTA whose full-time General Secretary, worked very closely with the Ministry of Education and UTA continued to grow. This was a reflection of a somewhat indirect/silent movement towards attracting intended outcome i.e. improved teachers' welfare. In this respect, UTA asked government to remove or deregister teachers who did not trade their line from the profession. This was the first indication that successful protest outcome is dependent on working with allies especially the ministry of education. This indicated that government prefers silent or supportive engagements as opposed to resistance or protests. However, failure to by UTA and UTU to harmonize their interest and issues of teachers' mutual concern remained a big challenge.

Efforts to merge the two organizations remained futile because they were seemingly pursuing different interests. The merger of 2003 resulted into the formation of the Uganda National Teachers Union (UNATU) with a dual role to promote professionalism as well as undertake trade union activities. The question however is, has this merger secured unity? Has it pursued the dual responsibility to the satisfaction of stakeholders?

\subsection{Teachers' Protests under the Uganda National Teachers' Union (UNATU)}

Currently, teachers in Uganda are organized under the UNATU which is a membership organization that comprises teachers at all levels (pre-primary to tertiary) and are affiliated to Education International (EI). Its mission is to promote and protect the social, intellectual, economic and professional interests of teachers as a pre-requisite to quality public education.

UNATU has been engaged in various forms of strikes, mass awareness campaigns on terms and conditions of service, conducted dialogues with parliament, government, asking for better salaries and improved teachers' welfare. Teachers' attrition especially teachers' resignation is attributed to job dissatisfaction arising from low levels of remuneration (MoES, 2013).

\subsubsection{Mobilization and Protest Strategies}

Data from interviews and focused group discussions with post graduate students on public policy studies course as well as UNATU officials show that various strategies have been adopted by the teachers protest movement. UNATU engages a wide range of strategies to realize its mission including Advocacy, Research, Collective Bargaining, Training, Publication, Networking, Policy Development and Multi-stakeholder Partnerships. The Teachers' Union (UNATU) participates in education policy development including development of Education Sector Strategic Plans.

UNATU has been organizing protest strikes, mass awareness campaigns on terms and conditions of service and has been lobbying government to improve on teachers' welfare. Teachers were mobilized to challenge their welfare issues by actively participating in industrial actions such as strikes, engaging district education officers, Negotiations, Lobbying local politicians and members of parliament, Media awareness campaigns through talk shows and sending of text messages to members, and explaining to stakeholders' issues surrounding teacher's welfare. Representatives of teachers associations at lower levels work hand in hand with national executives to stage protests and mobilize fellow teachers.

UNATU maintains open communication and kept members informed, through telephone calls, dissemination of The Teachers Voice Newsletter Just like Good fellow (2013) said with new social movements, the issue of communication is very critical. These strategies have been used in circumstantial manner and applied simultaneously where members of UNATU felt they were applicable. UNATU noted that advocacy has been their first line of options and protests or strikes are always last resort strategies. The mobilization strategy involved and reached many actors at different levels. According to Goodfellow 2013, taking issues of advocacy to occupy the public space is often regarded as an important 
aspect of social movements. Often it may provide a stepping stone towards further efforts that will yield teachers' welfare. The assumption here is that, given the level of participation, the teachers' priorities including salary increment would be addressed by government. What remains unclear is; has the UNATU protest strategies resulted into improved teachers' welfare?

Another strategy has been silent protests. Teachers have forced to engage in various forms of 'silent' protests such as using valuable teaching time to undertake private businesses. Individually, some teachers find their own alternative solutions. As one of the NOTU officials said:

We have been fighting for teachers' welfare and general management of the pay roll-you see teachers earn very little; even the little they earn is never given to them on time. You find a teacher instead of teaching they are engaged in other businesses like motorcycle riding as an alternative source of income. This time they use on boda-boda should be invested in teaching in class, but surely how can you teach for one or three months with no or enough salary and you are expected to continue working? Teachers work in poor conditions and this affects their performance. For instance in some schools there no enough classroom facilities to the extent that sometimes the teachers- instead of working they are always worried by hash conditions such as rain or too much sun shine (UNOTU)

These forms of emerging behaviours in a way portray a silent protest, that help the teachers to get additional /more income, reduced dependency on one source of income thereby improving on their welfare. Just like Goodfellow (2013) noted, this informal trend results from oppression and unyielding efforts to secure teachers' welfare. This kind of silent protests differ from that experienced in the historical days of teachers movements in Uganda, while during colonial days teachers would be on silent protest would go to class and teach. The new silent protest teachers are not in class but on alternative job chores.

\section{The Effect of Collective Action}

Through the above protests, UNATU has registered some successes. It continues to hold onto government promises to improve the teachers' salaries. Some of the successes include increased unity among teachers, finding alternative forms of protest, growing support from other actors, and improved salaries

\subsection{Increased Teacher Solidarity}

The mobilization of teachers to undertake industrial action towards their welfare inadvertently contributed to the growth and increased solidarity of the membership. UNATU membership has steadily increased as shown in the table below:

\begin{tabular}{|c|c|c|c|c|c|}
\hline & Decemb & Decemb & December 2011 & December 2012 & December 2013 \\
\hline 69,300 & 77,992 & 79,069 & 81,301 & 83,000 & Over 100,000 \\
\hline
\end{tabular}

One Important aspect emerging from the mobilization of teachers is that there is increased solidarity among teachers. The visibility of UNATU has increased and the Teachers Union is being seen as good 'voice' to reach out to teachers. During the protest movements UNATU memberships listen to their leaders more than they would listen to government. For instance, 'although politicians were telling teachers to stop striking and go back and teach, the teachers couldn't until we told them to go back (UNATU official). There is some kind of power shift, i.e. teachers have to some extent lost trust and confidence in government- they have more respect for the union and they would report to us those who would not respect the Unions position and or identify with the cause" (UNATU Official). This emerging unity presents potential for further exploitation by the teachers' union in future negotiations and protests against an unfair welfare system.

\subsection{Improved Salaries}

There have been some improvements on teacher's salaries resulting from their protests. For instance

- In 2006, the issue of teachers' salary increment was debated in parliament, and it eventually attracted some promises of salary increment of $25 \%$ for financial year 2015/16.

- In the same year (2006), government of Uganda made an attempt to address the salary question by instituting the public service pay reform that aimed to remove inequalities in wages of civil servants of similar grade jobs, effected pay increases for some categories of staff e.g. science teachers and researchers, and instituted new salary structure. The new salary strategy also set out long term pay targets to be implemented over a 10 year period (MoES, 2013).

- The government has put in place a welfare policy that include provision for salary grading, salary increments, other benefits such as medical, hardship allowances -for those working in hard to reach places etc. The implementation of the welfare guidelines and packages is influenced by the economic growth, priority setting 
during planning and budgeting processes (MoES, 2013). The Teachers' Union (UNATU) participates in education policy development including development of Education Sector Strategic Plans.

- Government fulfilled its commitment to enhance teachers' salaries by $15 \%$ for financial year $2012 / 2013$ although it did not fulfil its 20\% increment commitment for FY 2013/14

- Government promised to increase teachers' salaries by $25 \%$ in financial year $2014 / 2015$

- Science teachers are already receiving the science teachers' allowance of $30 \%$

- Pay slips which had stopped, now government has released money to print slips for teachers

- Teachers' fights contributed to salary increment of all civil servants across the board in financial year 2014/15, but teachers' pay has continued to be low.

- Government promised to increase teachers' salaries by $10 \%$ in financial year 2015/2016 but this increment has not been reflected in the budget thus the continued protest in May 2015.

- The May 2013 teachers protect attracted a promise of $15 \%$ increase in teachers' salaries in the government budget of 2016/2017.

\subsection{Improved Housing and Funding for Teachers SACCO}

Other achievements of Teachers' Protest Movements have been in areas of improving learning environment and teachers' housing.

- Capitation grant has for the first time in many years been released on time

- Teachers housing scheme which had been stopped is being initiated

- Teachers Savings and Credit cooperative (SACCO) formed in 2012 with total membership of 917 teachers and government promised UGX 25billion within a period of five years and it is only in 2013 that 5billion was included in the budget for 2013/2014. However, this fund was entrusted with Micro Finance Support Centre for management. This is because there has been a claim that teachers are not able to manage this funding. The issue of managing the SACCO money was one of the issues raised during the May 2015 teachers protest.

- The end of protest of May 2015 saw government given up to September 2015 to have the 25billion shillings channeled through the teachers SACCO rather than the Micro Finance Support Centre. The teachers will then directly manage the fund.

Though these achievements have been made, they come in a piece meal manner and they seem not to cause any structural change in the way the welfare issues of teachers are handled. Teachers are continuously faulted for their industrial actions and are blamed for the deteriorating standards of education.

\subsection{Growing Support from Partnerships and Networks}

Several alliances have been built with actors like NOTU, Church leaders, NGOs and Education International, and has had strategic working relationships with government. These alliances have been a source of strength, advice, and financial support to the campaigns. As UNATU officials narrated:

During the strikes NOTU, and Education International (EI)- EI wrote solidarity letters to UNATU and government, EI gave financial support for trainings and research while. NOTU issued statements and gave ultimatums to government on behalf of teachers. It also participated in parliamentary coalitions and provided legal support. Under the citizen's campaign for quality education- UNATU undertakes campaign jointly with UJCCC, ACTION AID, NGO FORUM, and UMEA. During our protests, all organizations helped in mobilization (UNATU).

Working in collaboration with other institutions, UNATU secured massive support and reached many teachers than would have been possible. The participation of many organizations gave the teachers' protests a citizen's voice; it ceased to be a teachers' only concern. Working in a network arrangement helped the movement not to easily be curtailed or compromised by government bureaucracies

In addition, UNATU protests have afforded to create strategic alliances with government so as to improve the education system. This was echoed by the Ministry of education official that:

UNATU works with government; they are represented on most education related fora. They participate in education sector reviews, they are able to shape policies, and they attend education consultative meetings where they are able to articulate their issues. They can also present their issues through the Ministry of education departments and agencies (UNATU).

Although the above observation contradicts teachers concerns over limited involvement in decisions regarding teachers' 
welfare, the protest movements of teachers have resulted into a number of successes.

\subsection{Policy Reforms}

In addition, the protest movement has resulted in some policy reforms in the education sector. UNATU has signed a Memorandum of Understanding with government committing to work together to improve the quality of education as well as the general teachers' welfare in Uganda. This achievement was confirmed by an official from the ministry of education and sports who noted that

To some extent there have been some reviews. For instance one of the issues teachers raised was that there were many 'Ghost'teachers. Which is true. They were saying that if these ghosts are identified, then government would save money to increase their salaries. Although teachers were tasked to identify these ghosts, government now recognizes it as an issue. But I think there is a whole reform now going on. Government through the office of auditor general is doing a bio-metric validation of all civil servants. This is one of the successes, it may not be totally attributed to teachers but, they added on the pressure for such reforms to happen now.

The persistent strikes and protest by teachers every financial year shows that government has not yet crafted a long lasting solution to teachers' welfare issues. There is no strategy and policy for salary enhancement as each of the policies calls for a negotiation between teachers and government with no already made solution.

\section{Success Factors and Challenges}

\subsection{Success Factors}

Attainment of the above successes towards teachers' welfare according to UNATU was attributed to three major factors that relate to leadership, a clear protest road map, and public campaign.

- The strong leadership of UNATU. As UNATU official noted, 'our leader is assertive, he is confident and with a good resolve';

- For every other strike UNATU develops a clear roadmap for the industrial action. UNATU official noted 'our protest wasn't abrupt; we followed procedures and exhausted all avenues for negotiation'. Although it was not followed to the dot for instance the strike ended hurriedly and UNATU did not get a proper chance to inform it members but the plan provided some guidance for the protests;

- Effective public campaigns. As UNATU official noted 'we also invested a lot in communication through SMS, sensitization campaigns'. This means that there was a planned effort by UNATU to occupy the public arena and keep the public informed.

- In the May 2015 teachers protest, members of parliament, opposition leaders, civil society organizations, and, to some extent teachers in private schools joined the protest and called upon government to attend to teachers' welfare issues. As one of the teachers from a private school was quoted saying 'we call upon government to priorities human capital development as an urgent matter because this standoff offers unacceptable loss of time and teachers contact with pupils' (Daily Monitor, Wednesday May 27, 215

\subsection{Constraints to Attainment of Teachers' Welfare}

Although teachers protests have yielded some successes, the general teachers' welfare remain a challenge since most of the successes are a response to a particular demand and not so much of an institutional change aiming at addressing the welfare issue in a sustainable way.

Lack of a holistic approach-There has been persistent reservation by government to increase salaries citing constraints related to; rapid growth of public employment, insufficient wage provisions in the national budget. Government has therefore been providing selective increment of wages for particular categories of staff for instance science teachers. The TISSA report shows that there has been no major pay increase recorded since 2004/05 among secondary teachers and their real wages have steadily been decreasing. Their pay has only been augmented by contributions from members of the Parents Teachers Association (PTA). Although the science teachers at secondary and tertiary levels have been given a 30\% allowances, the Art teachers, as well as BTVET lecturers' salaries have not been enhanced (MOES 2013).

Limited systems outlook-Inadequate involvement of other stakeholders and limited focus on key strategies for successful implementation of the reforms still remain a constraint to teachers' collective action. Mbabazi et al., (undated) attributed this to the political economy of education reforms which has been characterized by top down implementation with limited consultation with teachers, parents and children. This is further attributed to poor devolution of education to local government levels, leading to limited supervision by local leaders and limited accountability of education institutions. This is also echoed in the MoES Report (2013) where a limited systems outlook towards education policy development seems to account for an apparent gap in articulation of policy considerations that would cater for all inputs 
that would lead to effective implementation of the Teachers' welfare system.

While welfare has been an issue of common concern, teachers' protests have not effectively influenced government in institutionalizing a system to handle welfare issues. Although promises of salary increment were made, no mechanism is in place to ensure the promises are met and the issue of welfare is sustainably handled. This has been attributed to the weaknesses in the protest strategies utilized by UNATU and the threats existing in the broader socio-economic context within which teachers operate.

Limited Research by the teachers' movement-There is limited research done by UNATU regarding teachers' welfare. For instance UNATU highlighted the issue of 'ghost' teachers whose payments may be negatively affecting the overall teachers' wage bill. However, UNATU did not provide actual numbers and location of such 'ghost' teachers. Although government was convinced that this is an issue that affects teachers' welfare, it could not raise salaries due to lack of comprehensive information. While this may not be the sole reason for failure to increase teachers' salaries, it weakened UNATU's advocacy efforts.

Loop holes in mobilization for collective action-The mobilization of teachers has remained a challenge to UNATU. It is indicated that UNATU, being a voluntary membership organization, cannot force teachers to be its members. While this observation is valid, it prompts one to question whether or not the issue of collective concern is strong enough to compel members to join UNATU? Why would UNATU find it difficult to attract teachers to become members unless the issue of mutual concern is not in existence or is not strong enough? These questions are partially answered by the finding that there is a divide in the conditions of service for primary and secondary school teachers. Therefore because of salary differences teachers in secondary schools may not join UNATU. Evidently teachers in secondary schools do not participate in UNATU's industrial actions mostly it is the primary school teachers who turn up. Similarly teachers in private schools are not as desperate as their counterparts in private schools. They continue to teach even when those in public schools are on strike, thus weakening the 'would' be collective action. As such schools are likely to complete the syllabus compared to public schools. A bigger dynamic is that often teachers in private schools are sometimes the same teachers in public schools, thus they are seen as playing double standards and holding government at ransom. This has made teachers in public schools look more like jokers and opportunists. Evidently, the lack of unity among teachers affects the collectivity of their efforts.

Lack of a big picture approach- The whole protest movements have been focused towards increasing teachers' salaries without referring to the outcomes of increased salaries yet this is seen as critical for government. As one government official narrates:

There is a culture of poor attitude to work yet expecting better pay -this is an un-acceptable behaviour that may not justify attention to their demands. Teachers' demands for salary ought to be linked to their performance and attainment of overall education outcomes (Ministry of education and sports official)

Similarly, another government official observed that teachers' strikes are not based on a genuine foundation and they do not relate good salary to good service, after all they are permanent and pensionable as narrated below. ;

'Government teachers have poor attitude towards their work. If they do not teach they are not bothered, the world continues. If our children are not learning they are not bothered. So when an opportunity comes for them to strike, they just jump in and take advantage of not working. Those days they are on strike, they are busy in private schools teaching and or doing other businesses. Surprisingly, government pays teachers better than most private schools in this country why is it that those in private schools do not strike with the little salary they have? Even those who are not members of UNATU, when UNATU members are protesting, why do they join them? Teachers take government for granted, they know that they are permanent and pensionable and the procedure for dismissing a teacher from a government school is too long and frustrating. The Head Teachers are not given authority to dismiss teachers and they have tended to hold government on ransom (Government official).

The lack of a broad picture approach to teachers' welfare coupled with the existing poor attitude to work sends signals to government that teachers' protests are selfish and unjustifiable

Politicization of teacher's protests- The teacher's protests have moved from the question of teacher's welfare to a political blame game. Thus, different impressions have been formed among the teachers themselves, the public and government officials who view industrial action by teachers as an opposition statement to government.

The cause for teachers' protests in itself is good but how they undertake their industrial actions is an issue of debate. You know in this country we have politics, instead of addressing issues people start politicking. Before you know it there is a blame game. Teachers start saying there is no good will from government and government start blaming and intimidating teachers. Sometimes the opposition jump in and now things start being misunderstood. Although most people would naturally sympathize with teachers because almost each family in this country is 
affected by teacher's actions, but if you see people who are always demonstrating are also part of the teachers protest movement, then you start wondering whether teachers are fighting a genuine cause or a political issue. It is how the industrial action is packaged; it has a political connotation (Government Official)

This was also observed by UNATU itself which observed that their protests have been misunderstood by masses and as such some actors have been reluctant to identify with their efforts. A UNATU staff said:

The perception of masses is that UNATU is an opposition to government. The DEOs didn't want to identify with us for fear of losing their jobs. If people see us with Bishop Zac Niringiye who is an opposition activist, they conclude that UNATU is opposition and are opposing government policies (UNATU).

Fear of victimization/loss of jobs, unplanned transfers- similar to fears that characterized teachers actions in the early days of the teaching profession, majority of teachers in Uganda today are still hesitant to join industrial action for fear for their jobs or transfers to remote schools. However this is evidently changing with the May 2015 teachers protest. Almost in every public school, teachers did not teach for more that 8 days and teachers leaders went around radios mobilizing fellow teachers against going to class. Some teachers' leaders like in Kibale district were arrested and detained by police. On demand by fellow teachers their leaders were released.

Perceived low status of teachers in society- although the teachers protest movement has succeeded in bringing the issue into the public domain, a large section of society still regard teachers as a low status group. With this kind of community attitude, teachers protest have not attracted massive support from parents and other stakeholders as would be expected. This had had an effect on teachers' self-esteem and led to development of poor attitude towards their profession.

According to one of the teachers, the public has had bad attitude towards us, we are regarded as people of low status in society. This is because we cannot afford much in terms of wellbeing. We cannot afford taking our children to good schools and yet we spend day's teaching other people's children. We teach ministers, members of parliament and any other big person in this country, but even when these big people bypass a dying teacher along the road, they may not stop to give assistance to such a teacher to hospital. Our teachers die simply because they cannot afford medical bills, they cannot eat well, they cannot dress well, they do not have good housing and yet they teach every day. So should you expect good attitude from such teachers? Let others with good attitude come and work. Who can bear such situations and conditions? (One Teacher)

Minimal attention to professionalism during the teachers' protests-Failure to focus on professionalism is one of the reasons why teachers' protests have not attracted full government support as one government official noted:

The teachers who love their profession and can teach let rain or shine are less than 50\% of all the teachers we have. The rest are in this profession by accident. You know some years ago, if your son or your daughter failed to go to university then the option would be to take such a person to teaching. So people studied teaching profession as a last resort, they do not have the affection and the love of what they do. As also you know government colleges are fully sponsored so if parents fail to secure money for university education they will take you to teaching colleges for free education. Therefore when an opportunity of protests comes, majority will jump in to strike. Yes we agree teachers' welfare is an issue but, teachers ought to redeem their profession. Instead of lamenting that we are mere teachers, let them protest against abuse of the profession and be proud in their profession. If you go into rural areas, those who are drunkards, defilers of children, child neglectors, thieves etc. are teachers. In fact if they were talking of redeeming their profession of such vices, then government would listen. Teachers showing their children that even when you do not teach it is okay. Then how do you blame workers who go through their hands for not working. Where do they get money to drink the whole day anyway? These are issues NOTU should be talking about. (Government official)

\section{Conclusion}

Continued teachers protests and strikes over the years is a clear indication of the unresolved issues surrounding teacher welfare.

While teachers' protests have an issue of collective concern which transcends individual interests i.e. teachers welfare, there is no common commitment regarding the HOW to pursue this common concern. As such some teacher engage in protest while others do not, and or protest silently

Teacher's protests have adopted characteristics of the old and new social movements. They have planned protests, they have built strategic alliances, and have heavily utilized public spaces to demand for improved welfare.

There has been incremental achievement on some aspects of teacher's welfare such as salaries and housing. However, these still lack a comprehensive institutional and policy frameworks to guarantee sustainable changes in teacher's 
welfare.

Teachers protests have contributed some improvement towards teachers welfare (policy and operational aspects), teachers movements are still constrained by limited research by UNATU, loopholes in mobilizing teachers, failure to focus on broader outcomes of protests, politicizing of protests and failure to bring in the issue of teachers professionalism. Thus the prospects for teachers protests to cause welfare changes in the current welfare status of teachers is dependent on proper mobilization of different categories of teachers as well as their ability to link welfare-professionalism and attainment of the education outcomes.

\section{References}

Abbie (2012). Education in Crisis- Monitoring Analysis and Resources for Education Activism: a 2012 EI Country Study Report

Gemma, E. Herbamas, Activism, and Acquiescence: Reactions to 'Colonization' in UK Trade Unions-school of social sciences, Sociology, University of Manchester, UK

Goodfellow, T. (2013). The Institutionalization of "Noise" and "Silence" in Urban Politics: Riots and Compliance in Uganda and Rwanda

Kingstone, C. (2008). Institutional Change-Comparing Theories of Institutional Change, Amherst College

Martha, G. \& Hessel, et al (1949). American Research Association-Volume XIX, No.3: Welfare if the Individual Teacher, Review of Educational Research

Ministry of Education and Sports (2013). Teachers initiative in sub-Saharan Africa (TISSA) Teacher issues in Uganda: Diagnosis fora shared vision on issues and the designing of a feasible indigenous and effective teachers' policy-

Piven, C. (1966). The Weight of the Poor: A Strategy to End Poverty, Issue of the Nation

Susanne, J. (2014). Identifying Environmental Threats to Success: CIPD and the HR Profession

Toloudis, N. (2008). Instituteur Identities: Explaining the Nineteenth Century French Teachers' Movement

The Daily Monitor, End of Strike: Teachers Agree to Resume Classes. Wednesday May 27, 2015 no. 146

Uganda National Teachers' Union Newsletter (2013).

Wolff, J. (2007). (De-)Mobilising the Marginalised: A Comparison of the Argentine Piqueteros and Ecuador's Indigenous Movement. Journal of Latin American Studies, 39(01), 1-29.

\section{$(c)$ BY}

This work is licensed under a Creative Commons Attribution 3.0 License. 